\title{
Cytoprotective Effects of (-)-Deprenyl Might be Due to its Estrogen Receptor Stimulatory Activity in Vitro
}

\author{
Zsuzsanna Kocsis $^{1}$, Zoltán Marcsek ${ }^{1 *}$, Mátyás Jakab ${ }^{1}$, Anna Tompa ${ }^{2}$ \\ ${ }^{1}$ National Public Health Institute, Department of Experimental Toxicology, Budapest, Hungary \\ ${ }^{2}$ Semmelweis University, Institute of Public Health, Budapest, Hungary
}

*Corresponding Author: Zoltán Marcsek, National Public Health Institute, Department of Experimental

Toxicology, Budapest, Hungary

\begin{abstract}
The dose-dependent anti-apoptotic and neuroprotective effect of (-)-deprenyl (Selegiline, Jumex) is confirmed. The cytoprotective effect may extend to both neuroectodermal and non neuroectodermal somatic cells. The aim of this study was to demonstrate the cytoprotective and anti-apoptotic effect of deprenyl using a liver tumor cell culture (HepG2) and a tumor cell line originated from human breast tumor (MCF-7) and the antioxidant properties on the HepG2 cell line. The dose-effect relationship of (-)-deprenyl was investigated keeping the cells under optimal culture conditions or in serum-deprived medium. (-)-Deprenyl treatment did not exert toxic or anti-proliferating effect on non-starved HepG2 and MCF-7 cells. However, following serumdeprivation the rate of apoptosis was reduced and cytoprotective effect was detected in low dose (1-100 nM) (-)-deprenyl treated cell cultures, compared to the control. In high dose (100 $\mu M)(-)$-deprenyl increased apoptotic ratio and reduced viability of the serum deprived cultures. The antioxidant capacity measured by chemiluminometry of Hep 2 cells upon $(1 \mathrm{pM}-10 \mu \mathrm{M})$ (-)-deprenyl treatment significantly increased. In MCF7 cells $1 \mathrm{nM}$ and $10 \mu \mathrm{M}$ (-)-deprenyl treatment intensified the estrogen receptor transcriptional activity measured by real time PCR.

In conclusion (-)-deprenyl exerts dose-dependent anti-apoptotic effect on starving non-neural ectodermal cells. The major new result of our experiments is that the survival of estrogen-responding MCF-7 cells in serum deprived culture is supported and the estrogen-dependent transcription in there cells is activated by (-)deprenyl. This phenomenon may broaden the pharmacological application of (-)-deprenyl.
\end{abstract}

Keywords: (-)-deprenyl, cytoprototective effects, estrogen receptor, apoptosis, MCF-7, HepG2, MTT assay

\section{INTRODUCTION}

Deprenyl, a methyl amphetamine derivate with a propargyl group, attached to the nitrogen was first described by Knoll et al. (1965).

As a MAO-B inhibitor (-)-deprenyl inhibits the oxidative de-amination of dopamine, the common substrate for MAO-A and MAO-B (Knoll and Magyar, 1972).

Birkmayer and his group were the first to find (-)-deprenyl effective in clinical treatment of parkinsonian patients (Birkmayer et al., 1975) and they were also the first who suggested deprenyl being neuroprotective based on a retrospective clinical study (Birkmayer et al., 1985). (-)-Deprenyl became the only MAO-B inhibitor used during three decades to treat parkinsonian patients.

The actual redoxy homeostasis depends on the concentration of free oxygen-radicals. Changes in the redox state regulate the expression of a series of genes through the activation of transcription factors. MAO-B activity age-dependently leads to an increasing formation of $\mathrm{H}_{2} \mathrm{O}_{2}$, the main source of oxidative radicals (ROS) (Fowler et al., 1980, Saura et al., 1994). (-)-Deprenyl, as a derivative of propargylamine, activates both forms of superoxide dismutase (SOD) as well as the catalase enzyme participating in the inactivation of hydrogen peroxide (Carillo et al., 1994).

Besides this, deprenyl changes the gene expression level of NO synthase, bc12, bc1-XL, c-jun and NAD-dehydrogenase (Szende et al., 2001).

The anti-apoptotic activity of (-)-deprenyl was first reported by Salo and Tatton in 1992 who presumed that its metabolites were responsible for the effect. The anti-apoptotic and neuroprotective effect of 
deprenyl was proven using numerous in vitro and in vivo models (Tatton et al., 1994; Magyar et al., 1998; Magyar et al., 2004; Tatton, 2000; Tatton et al., 2002; Szende et al., 2000; Szende et al., 2001).

Estrogen is one of the hormones that regulate numerous functions of many tissues by its transcriptionmodulatory action. Neuroprotective effect of estrogen and the selective estrogen receptor modulators (SERM) in cases of brain damage of various origin resulting in neurodegenerative and cognitive disorders is well known (Behl, 2002; Liu et al., 2010, Brann et al., 2007) but its molecular mechanism has still not been clarified.

The aim of our presented investigations was to study the cytoprotective effect of (-)-deprenyl in vitro cultured non-neuroectodermal cell lines. At the same time by applying the estrogen-dependent cell line (MCF-7) the possible estrogen receptor activating property of (-)-deprenyl could be studied.

\section{Materials ANd Methods}

\subsection{Cell Cultures and Growth Conditions}

The experiments were carried out on estrogen receptor positive (ER+) HepG2 (ECACC 85011430) human liver carcinoma and on ER+ MCF-7 (ECACC 86012803) human breast carcinoma cell lines. The cells were cultured in a humified $5 \% \mathrm{CO}_{2}$ thermostat at $37^{\circ} \mathrm{C}$ in Dulbecco's medium (DMEM) complemented with $10 \%$ heat-inactivated fetal calf serum (FCS), L-glutamine, and penicillinstreptomycin.

(-)-Deprenyl, 17ß-estradiol (E2), ICI 182,780 (ICI), MTT reagents were from Sigma-Aldrich Co. (St. Louis, USA), the nutrient media DMEM, trypsin-EDTA solution, PBS, L-glutamine and fetal bovine serum from Invitrogen Gibco Ltd. (UK), culture dishes were from Nunc (Thermo Fisher Scientific, Inc., Denmark).

\subsection{Treatment}

For cell cycle studies and ER activation experiments 106 cells were seeded in $100 \mathrm{~mm}$ Petri dishes and treatments were applied after $24 \mathrm{~h}$ of pre-incubation. Cells were kept in serum-free condition for three days to induce apoptosis and at $72 \mathrm{~h}$ substances being tested (E2, ICI 182,780, (-)-deprenyl) were added for further 24 and $48 \mathrm{hrs}$. Experiments were repeated three times and three parallel dishes were used for each concentration. Controls were kept in serum-free DMEM.

\subsection{MTT Viability Assay}

Cytotoxic effects on the growth and viability of $2 \times 104$ cell/ml were determined in 96-microwell plates using tetrazolium dye MTT (3[4,5-di-methylthiazol-2-yl]-2,5-diphenyltetrasolium bromide) assay, as described (Mosmann, 1983; Horiuchi et al., 1988; Cory et al., 1991; Kocsis et al,. 2005). Optical density (O.D.) of the wells was determined using an Anthos 2020 (Salzburg, Austria) enzyme-linked immunosorbent assay (ELISA) microplate reader at a test wavelength of $570 \mathrm{~nm}$ and a reference wavelength of $690 \mathrm{~nm}$.

All MTT experiments were performed at least three times with four parallel wells for each concentration in the range of $0.1 \mathrm{pM}$ to $100 \mu \mathrm{M}$ of (-)-deprenyl. The control cells were grown under the same conditions without the addition of the test compounds. Cell survival (\%of control) was calculated relative to untreated controls.

\subsection{Chemiluminescent Measurement of Total Scavenger Capacity}

96 well cell culture plates were used for the measurement of antioxidant capacity plating 3000 HepG2 cells per well. The total scavenger capacity of $0.1 \mathrm{pM}$ to $100 \mu \mathrm{M}(-)$-deprenyl on HepG2 cell cultures was detected by chemiluminometric method in the $\mathrm{H} 2 \mathrm{O} 2: \mathrm{OH} \bullet-$ luminol-microperoxidase system using a Total Scavanger Capacity (chemiluminometric) kit of Diachem Ltd. (Budapest) (Blázovics et al., 1999) and a Victor3 multilabel reader (PerkinElmer, Waltham, MA, USA). Wallac 1420 software (PerkinElmer-Wallac, Turku, Finland) was used for data analysis. The intensity of the emitted light is proportional to the amount of free radicals present in the reaction. In the presence of scavenger compounds the intensity of the measurable light declines depending on the concentration of free radicals.

(-)-Deprenyl was applied to HepG2 cell cultures in the final concentration of $0.1 \mathrm{pM}, 1 \mathrm{pM}, 10 \mathrm{pM}, 100$ $\mathrm{pM}, 1 \mathrm{nM}, 10 \mathrm{nM}, 100 \mathrm{nM}, 1 \mu \mathrm{M}, 10 \mu \mathrm{M}, 20 \mu \mathrm{M}$ and $30 \mu \mathrm{M}$ for $24 \mathrm{hrs}$. The total scavenger capacity was determined by using Diachem kit and luminescence values were read by Victor3 multilabel reader (Perkin-Elmer) in luminometry mode and data were analyzed by Wallac 1420 (Perkin-Elmer) software (Hagymási et al., 2001). 


\subsection{Flow Cytometry}

HepG2 and MCF-7 cells were cultured for $24 \mathrm{hrs}$ in $100 \mathrm{~mm}$ Petri dishes at an initial plating density of 1x106 cells/dish in DMEM containing 10\% FBS and antibiotics. After 24 hrs the media was changed to serum-free DMEM to induce apoptosis. $72 \mathrm{hrs}$ following serum deprivation cells were treated with (-)-deprenyl in the concentration range of $0.1 \mathrm{nM}$ to $10 \mu \mathrm{M}$ for 24 and 48 hours. Pulse labeling of cells with $5 \mathrm{mg} / \mathrm{ml} 5$-bromo-2-deoxyuridine (BrdU, Sigma) was performed $2 \mathrm{~h}$ prior to the termination of the cultures.

For the determination of the cell cycle phases, DNA was stained with propidium iodide (PI) and the incorporated BrdU was detected immunocytochemically with FITC-labeled anti-BrdU monoclonal antibodies (Becton Dickinson, USA). DNA denaturation prior to PI and FITC-anti-BrdU staining was performed at room temperature using a modification of the method described by van Erp et al. (1988).

The cells were analyzed by flow cytometry in a FACSCalibur (Becton Dickinson, USA) system at a flow rate of approximately 400 cells/s. CellQuest software (Becton Dickinson, USA) was used for data analysis. The percentages of apoptotic fractions were determined on the basis of PI and anti-BrdUFITC/PI fluorescence.

\subsection{Measurement of Estrogen Receptor Activation in MCF-7 Cells}

106 MCF-7 human breast adenocarcinoma-derived cells were plated in $100 \mathrm{~mm}$ Petri dishes and precultured in 5\% FCS completed DMEM in humified CO2 incubator at $37 \mathrm{oC}$ for $24 \mathrm{~h}$.

After the pre-incubation period (-)-deprenyl was added in the concentration series of $10 \mathrm{nM}, 100 \mathrm{nM}$, $1 \mu \mathrm{M} 10 \mu \mathrm{M}$ and $100 \mu \mathrm{M}$ for $24 \mathrm{~h} .1 \mathrm{nM} 17-\beta$ estradiol and $10 \mathrm{nM}$ of the estrogen receptor antagonist ICI were applied as positive and negative controls. ICI was applied simultaneously with all doses of ()-deprenyl as well as with 17- $\beta$ estradiol in order to confirm that the effects were mediated by ER.

At the end of the $24 \mathrm{~h}$ of treatment total RNA was isolated using the GenElute total RNA isolation kit (Sigma, RTN70) following the manufacturer's instructions. Reverse transcription was performed in 20 $\mu \mathrm{l}$ reaction volumes, using $1 \mu \mathrm{l}$ of isolated total RNA, $0.1 \mu \mathrm{g} / \mathrm{ml}$ oligo-dT12-18 primer (for transcription of mRNAs) and $500 \mathrm{nM} 18 \mathrm{~S}$-ribosomal RNA (rRNA) specific reverse primer (for transcription of $18 \mathrm{~S}$ ribosomal RNA used as internal control, see below the sequences) (Marcsek et al., 2004), $500 \mathrm{nM}$ of each deoxyribonucleoside triphosphates (Sigma, St Louis, USA), and buffer (shipped with M-MLV reverse transcriptase enzyme). Samples were denatured at $70^{\circ} \mathrm{C}$ for $10 \mathrm{~min}$ and $200 \mathrm{U}$ of M-MLV reverse transcriptase (GIBCO-BRL, Invitrogen Life Technologies, Paisley, Scotland) and 25U RNaseOUT Recombinant Ribonuclease Inhibitor (GIBCO-BRL, Invitrogen Life Technologies, Paisley, Scotland) at $37^{\circ} \mathrm{C}$ for 50 minutes.

Estrogen-receptor activity was monitored by the trefoil factor (PS2, presenilin 2) transcript formation. The pS2 gene has an estrogen-responsive element (ERE) in its promoter, so the amount of transcribed pS2 mRNA is proportional to the activity of ER (Knowlden et al., 1997). In the PCR reactions, parallel amplification of 18S rRNA was performed as an internal control (Schmittgen et al., 2000). The pS2-specific primers used were 5'CATGGAGAACAAGGTGATCTG3' and 5'CAGAAGCGTG TCTGAGGTGTC3' amplifying 336 bp DNA and 18S-rRNA primers were 5'GTAACCCGTTG AACCCCATT3' and 5'CCATCCAATCGGTAGTAGCG3' producing 151 bp PCR fragment. Primers were synthesized by the Genodia Co. (Budapest, Hungary).

The $20 \mu \mathrm{l}$ PCR reaction volumes contained $1 \mu 1$ st strand cDNA, $500 \mathrm{nM}$ of each primers, $3 \mathrm{mM}$ $\mathrm{MgCl} 2$ and 1xLightCycler DNA master SYBR Green I mix (Roche, Mannheim, Germany). Real-time PCR assays were performed in a LightCycler carousel-based system (Roche LC 1.2).

\section{STATISTICAL ANALYSIS}

Results were assessed by one-way analysis of variance (ANOVA) using GraphPad Prism (GraphPad Software, Inc., San Diego, CA, USA) Dunnett test application (all data were compared to the control) statistical analysis program. $P$ values of $p<0.05$ were considered to be significant.

\section{RESUlts}

\subsection{MTT Assay}

Under non serum-deprived conditions (-)-deprenyl did not show any cytotoxic effect in either cell lines in the studied concentration range (up to $100 \mu \mathrm{M}$ ) (Fig 1. a and b).

In the serum starvation experiments the high concentration of deprenyl $(100 \mu \mathrm{M})$ caused significantly increased cell death compared to the non-treated controls in both MCF-7 and HepG2cell cultures (Figs 
2 and 3). In case of HepG2 cell cultures with serum deprivation, low doses $(0.1 \mathrm{nM}-1 \mu \mathrm{M})$ of the (-)deprenyl showed a tendency of cytoprotective effect at 48 and $72 \mathrm{hrs}$, however, not at significant level, whereas no effect was found at 24 hrs (Fig. 2 b and c). Serum-starved MCF-7 cells at 48 and 72 hrs of (-)-deprenyl treatment in the concentration range of 1-100 $\mathrm{nM}$ exhibited a significant increase in viable cell population compared to the non-treated serum starved control.

\subsection{Flow Cytometry}

MCF-7 cells after 24 hrs serum-deprivation followed by treatment for $24 \mathrm{hrs}$ intervals (-)-deprenyl at 1 $\mathrm{nM}, 100 \mathrm{nM}$ and $1 \mu \mathrm{M}$ concentration in serum-free medium showed a significantly reduced apopototic rate by flow cytometry compared the untreated control. $10 \mu \mathrm{M}$ concentration of (-)-deprenyl was cytotoxic in MTT assay (Fig. 2. a, b). When the treatment interval was raised to $48 \mathrm{hrs}$ the extent of apoptosis did not change at lower concentrations and increased significantly at higher concentration (Fig. 4 A and B) while at low dosage the antiapoptotic effect was not detectable. HepG2 cell cultures after 24 hours serum-deprivation and consecutive treatment at $0.1 \mathrm{nM}, 100 \mathrm{nM}, 1 \mu \mathrm{M}$ and $10 \mu \mathrm{M}$ (-)-deprenyl concentrations for 24 and $48 \mathrm{hrs}$ after the treatment in three sequential concentrations (1100-1000 nM) exhibited significant antiapoptotic effect compared to the control. Similar effect was observed after $48 \mathrm{hrs}$ treatment with higher doses (1- $10 \mu \mathrm{M})$ (Fig. $5 \mathrm{~A}$ and B).

\subsection{Antioxidant Capacity}

(-)-Deprenyl $1 \mathrm{pM}$ and $10 \mu \mathrm{M}$ caused $20 \%$ significant rise in antioxidant capacity of non-serum deprived HepG2 cell cultures 24 hours after treatment (fig 6).

\subsection{Estrogen Receptor Activation}

(-)-Deprenyl at $1 \mu \mathrm{M}$ and $10 \mu \mathrm{M}$ concentration significantly induced the expression of the ER-regulated PS2 gene in MCF-7cells. $10 \mu \mathrm{M}$ (-)- Deprenyl treatment significantly raised the pS2 gene expression up to the level caused by $1 \mathrm{nM} 17 \beta$-estradiol used as positive control (Fig. 7). The presence of the estrogen receptor blocker ICI inhibited the (-)-deprenyl-induced pS2 gene expression (Fig. 7).

\section{DISCUSSION}

The dose dependent apoptosis inhibiting effect of (-)-deprenyl has been studied primarily in neuroectodermal cells and tissues both in vitro and in vivo (Salo and Tatton, 1992; Tatton et al., 1994). A few studies raised the possibility that the antiapoptotic effect is valid for tissues and cells of other histogenesis as well (Qin et al., 2003; Toronyi et al., 2002).

Results in our present study prove that (-)-deprenyl influences apoptosis and cell proliferation not only in neuroectodermal cells.

The anti-apoptotic effect of (-)-deprenyl depends on dose, cell type, culture conditions, longer or shorter serum deprivation and treatment time. The cell viability of non-starved HepG2 and MCF-7 cultures treated with (-)-deprenyl in the $0.1 \mathrm{pM}-100 \mu \mathrm{M}$ dose range did not decline. In fact, rather there was a slight, non-significant, rise in the population of viable cells.

Following serum deprivation, cultures treated with higher $(10-100 \mu \mathrm{M})$ concentration of (-)-deprenyl showed a significant decline in viability compared to the untreated control whereas low concentrations ( $1 \mathrm{nM}-100 \mathrm{nM})$ of (-)-deprenyl caused a significant viability increase in MCF-7 cell cultures after longer (48 and $72 \mathrm{hrs)}$ treatment. HepG2 cell cultures reacted the same way to deprenyl treatment as MCF-7 but changes in viability were moderate and not significant. The cytotoxic effect of $100 \mu \mathrm{M}(-)$-deprenyl was significant on both cell lines.

Changes in viability were reflected by changes in apoptotic ratio, as well. Our experiments prove that the cytoprotective effect of (-)-deprenyl extends not only to cells of CNS origin but also on other somatic cells, endorsing the possibility that the antiapoptotic effect of (-)-deprenyl is not based on MAO-B inhibition but rather on the stabilization of mitochondrial membranes or inhibiting the apoptotic pathway (Simon et al., 2005; Wadia et al., 1998) since neither MCF-7 nor HepG2 cells express MAOs (Jorgensen et al., 2000, Wong et al., 2002).

The anti-apoptotic property of (-)-deprenyl may have a favorable effect against cell death caused by hypoxia-reperfusion in various tissues and organs like heart muscle, arterial endothel, brain or kidney. At the same time reduced apoptotic activity may be accompanied by cell proliferation enhancing regenerative processes. With respect to this, as found in our earlier investigations, the anti-apoptotic and proliferative processes induced by (-)-deprenyl may not effect tumors of neuroectodermal origin as prolonged (-)-deprenyl application does not lead to elevated tumor progression (Magyar et al., 1998). 
In the case of Parkinson's disease the nigrostriatal dopaminergic lesion can be attributed to increased hydrogen peroxide, superoxide and hydroxyl radicals (Heikkila et al., 1972). Propargylamines increase the expression of certain antioxidant enzymes, superoxide dismutase and catalase (Carillo et al., 1991, 1994). In our experiments the anti-oxidant capacity of HepG2 cells was enhanced by all doses of (-)-deprenyl and remarkably interesting that this increase of antioxidant capacity shows two peaks, one at $1 \mathrm{pM}$ and one at $1 \mu \mathrm{M}(-)$-deprenyl treatment. Our results on HepG2 cells support that the antioxidant activity of (-)-deprenyl extends also to non-neural cells.

The role of estrogen on the onset and severity of neurodegenerative diseases is known as well as its potential role in neuroprotection (Brann et al., 2007). This effect is mediated by its target molecule, the estrogen receptor. ER is a transcription factor that regulates the expression of several genes playing role in apoptosis, metabolism, or cell proliferation control.

Estrogens were proven to have neuroprotective action (Liu et al., 2010; Brown et al., 2009; Saldanha et al., 2009) mediated by any of the known ERs (Toran-Allerand, 2004).

In our experiments performed on an ER-positive cell line (-)-deprenyl treatment resulted in higher viability of serum-starved cell cultures. Although (-)-deprenyl does not have a chemically similar structure to estrogen we found that it was able to activate ER-dependent transcription. The E2-acivated ER also influences the expression of apoptotic enzymes (Brann et al., 2007) so the anti-apoptotic effect of (-)-deprenyl might be comparable to a Selective Estrogen Receptor Modulator-like activity. Direct activation of estrogen receptor with (-)-deprenyl treatment indicates that (-)-deprenyl is able to induce gene expression changes similar to estrogen.

In other words the survival of estrogen responsive MCF7 cells in serum-free cultures is supported as well as estrogen receptor mediated transcription is activated by (-)-deprenyl in these cells.

The results of our experiments neither support nor disprove of a direct relationship between the cytoptrotective, the antioxidant, the antiapoptotic and the ER-activating properties of -(-)deprenyl. However, our knowledge about these properties - which seem to be extended from neuroectodermal cells to cells of different origin - may be exploited in practice and broaden the pharmacological application of -(-) deprenyl.
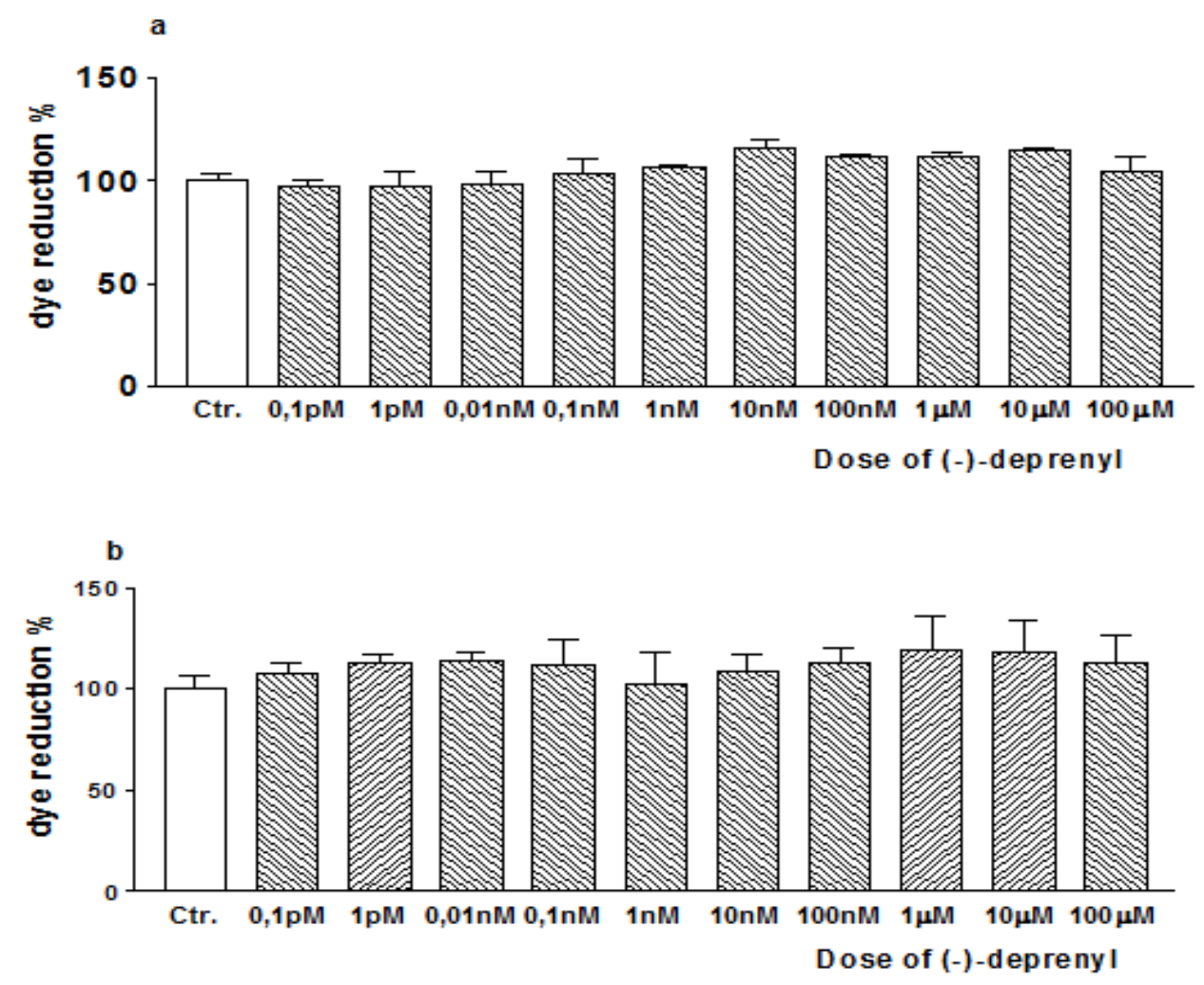

Figure1. The effect of (-)-deprenyl on the viability ratio of cultured HepG2 and MCF7 cells after 24 hours of treatment using serum supplemented medium (MTT assay, data are given in percent of the control). a: HepG2 cells, $b$ : MCF7 cells 

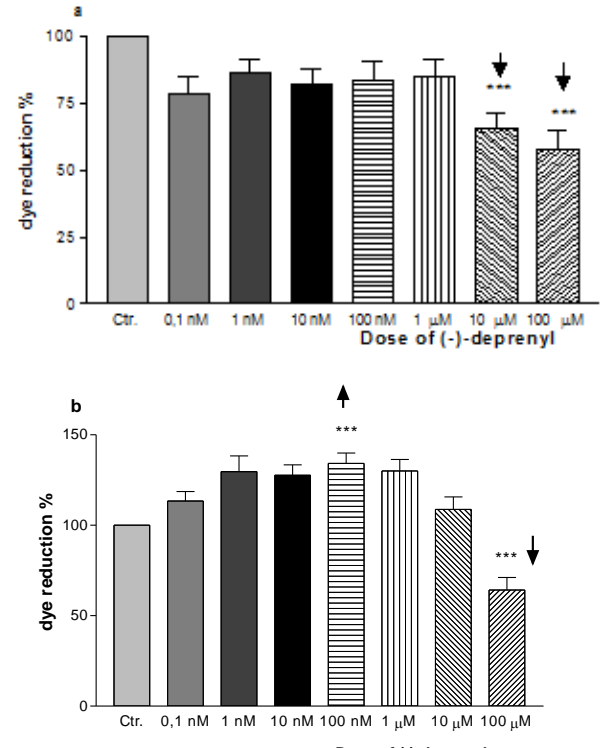

Dose of (-)-depreny

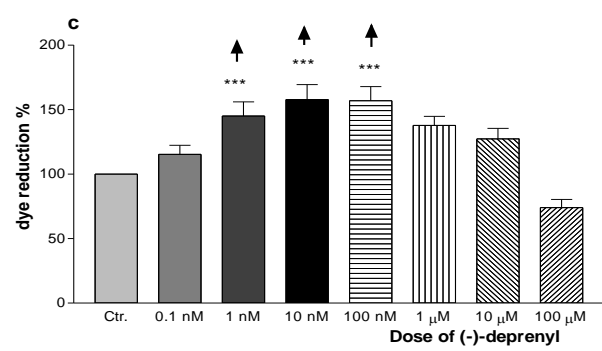

Figure2. Effect of various concentrations of (-)-deprenyl on the viability of serum-deprived MCF7 cell cultures. a: at 24 hours of treatment $b$ : at 48 hours of treatment $c$ : at 72 hours of treatment $(* * *=p<0.001)$ (MTT assay)
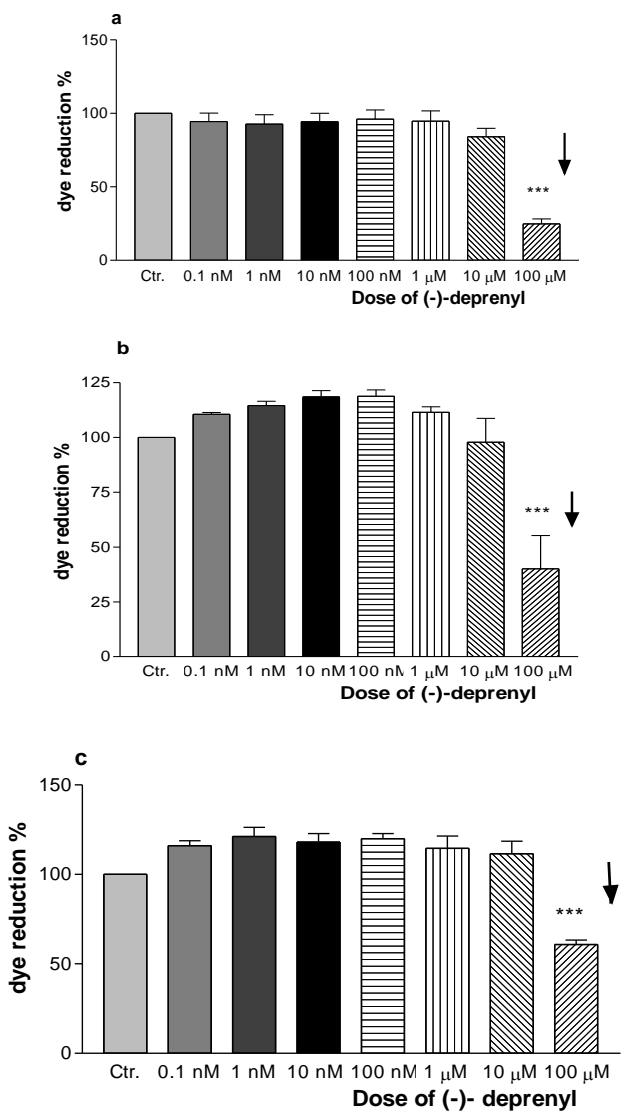

Figure3. Effect of various concentrations of (-)-deprenyl on the viability of serum-deprived HepG2 cell cultures. a: at 24 hours of treatment $b$ : at 48 hours of treatment $c$ : at 72 hours of treatment $(* * *=p<0.001)$ (MTT assay) 

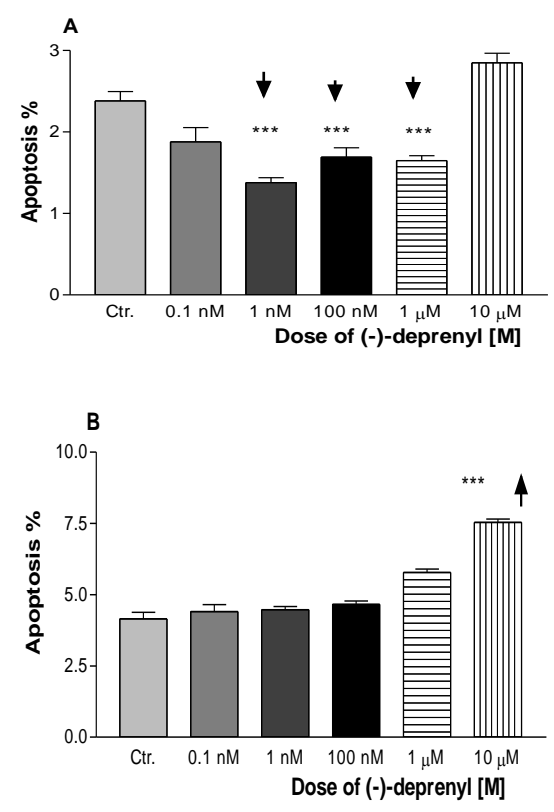

Figure4. Effect of various concentrations of (-)-deprenyl on the apoptotic ratio of 72 hours serum-deprived MCF7 cell cultures A: at 24 hours of treatment B: at 48 hours of treatment ( $* * *=p<0.001)$ (Flow cytometric analysis)
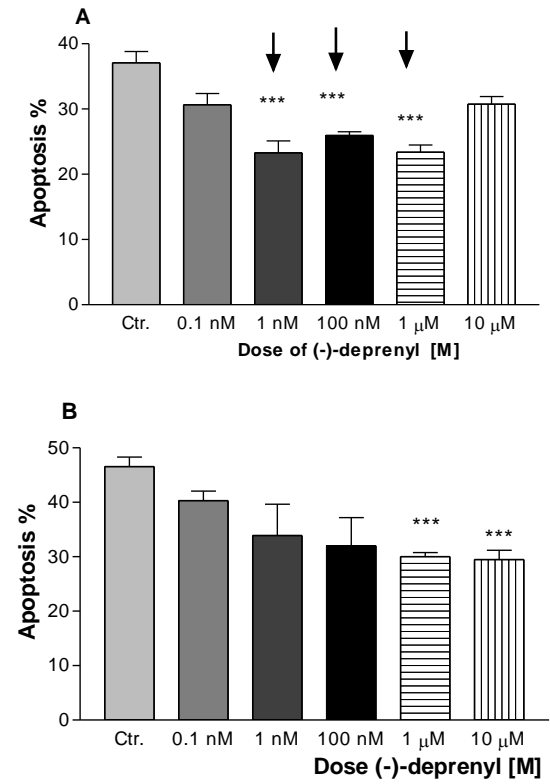

Figure5. Effect of various concentrations of (-)- deprenyl on the apoptotic ratio of 72 hours serum-deprived HepG 2 cell cultures A: at 24 hours of treatment B: at 48 hours of treatment $(* * *=p<0.001)$ (Flow cytometric analysis)

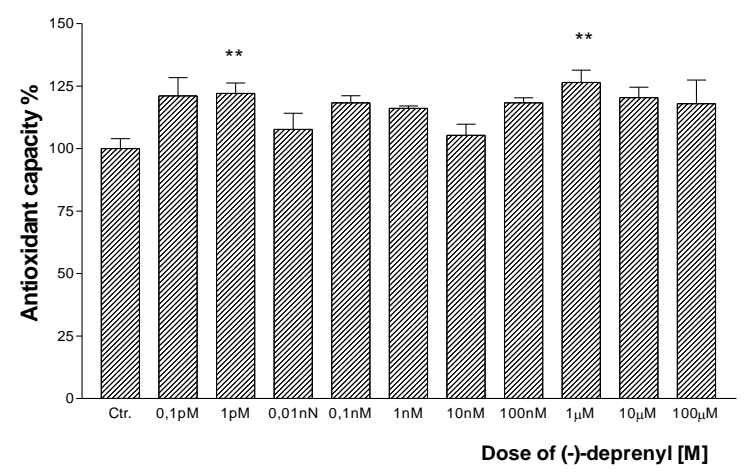

Figure6. Effect of various concentrations of (-)- deprenyl on the antioxidant capacity after 24 hours treatment of HepG2 cell cultures $(* *=p<0.05)$ (Chemiluminescent measurement of total scavanger capacity) 


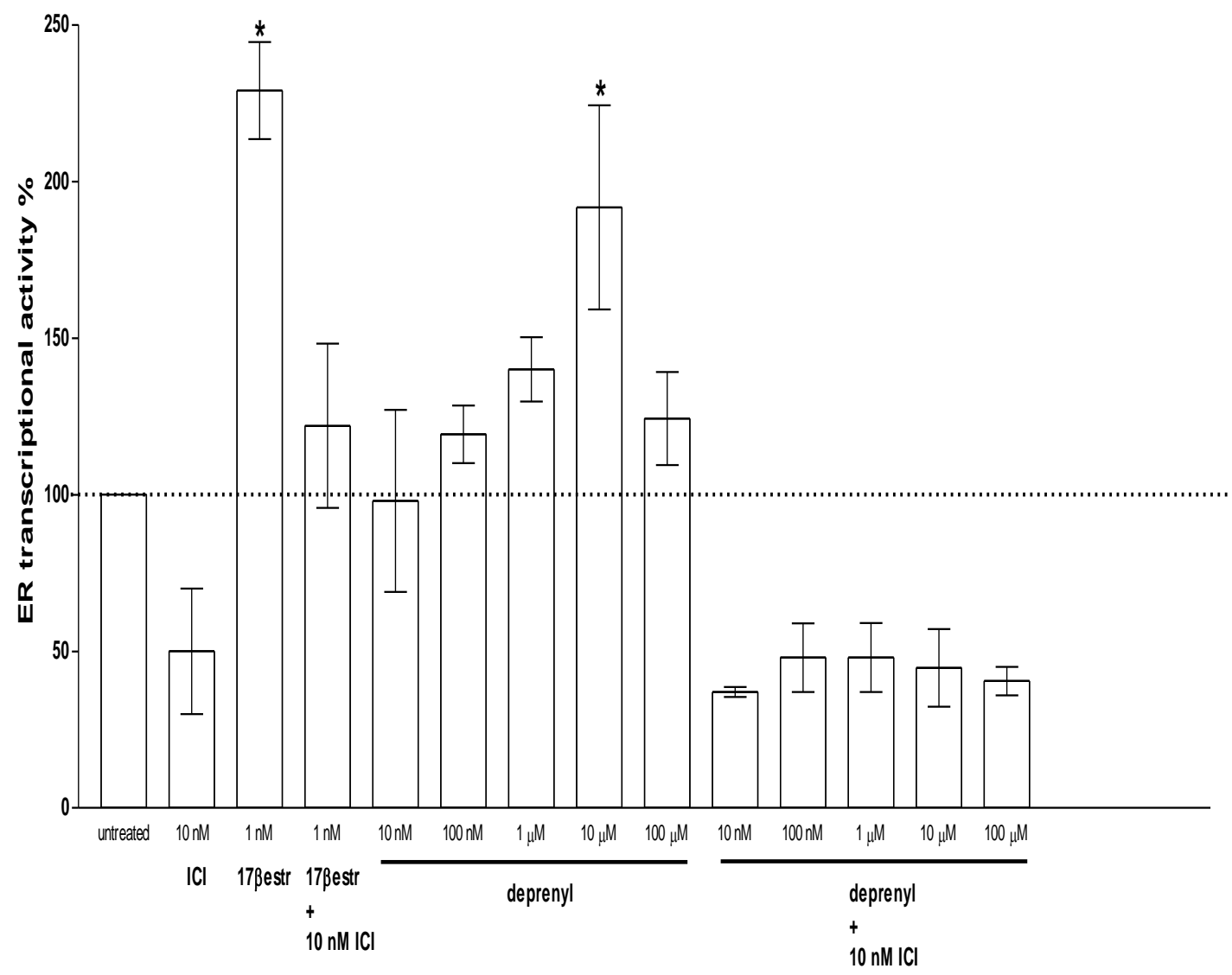

Figure7. Effect of various concentrations of (-)- deprenyl on the estrogen receptor activity after 24 hours treatment of MCF7 cell cultures $(* * *=p<0.001)$ (Real-time PCR assay)

\section{ACKNOWLEDGEMENT}

\section{Authors wish to thank Erzsébet Romhány, Veronika Deák and Brigitta Kovácsné Lukács for their excellent technical assistance in the performance of the experiments.}

\section{REFERENCES}

[1] Behl C (2002) Oestrogen as a neuroprotective hormone. Nature Reviews Neuroscience 3:433-442

[2] Birkmayer W, Knoll J, Riederer P, Youdim MBH, Hars V, Martin J (1985) Increased life expectancy resulting from addition of L-Deprenyl to MadoparR treatment in Parkinson,s disease: A long-term study. J. Neural Transm 64(2):113-127

[3] Birkmayer W, Riederer P, Youdim MBH, Linauer W (1975) The potentiation of the anti-akinetic effect of L-dopa treatment by an inhibitor of MAO-B, 1-deprenyl. J. Neural Transm 36(3-4):303-326

[4] Blázovics A, Kovács Á, Lugasi A, Hagymási K, Bíró L, Fehér J (1999) Antioxidant defense in erythrocytes and plasma of patients with active and quiescent Chron's disease and ulcerative colitis: A chemiluminescence study, Clinical Chemistry 45(6):895-896

[5] Brann WD, Dhandapani K, Wakade C, Mahesh BV, Khan MM (2007) Neurotrophic and Neuroprotective Actions of Estrogen: Basic Mechanisms and Clinical Implications. Steroids 72(5):381-405

[6] Brown CM, Suzuki S, Jelks KAB, Wise PM (2009) Estradiol is a potent protective, restorative, and trophic factor after brain injury. Semin Reprod Med 27(3):240-249

[7] Carillo MC, Ivy GO, Milgram NW, Head E, Wu P and Kitani K (1994) (-)-Deprenyl increases activities of Superoxide Dismutase (SOD) in striatum of dog brain. Life Sciences 54(20):1483-1489

[8] Carillo MC, Kanai S, Nokubo M, Kitani K (1991) (-)-Deprenil induces activities of both superoxide dismutase and catalase but not of glutatione peroxidase in the striatum of young male rats. Life Sciences 48(6):517-521

[9] Cory AH, Owen TC, Barltrop JA, Cory JG (1991) Use of an aqueous soluble tetrazolium/formazan assay for cell growth assays in culture. Cancer Commun 3(7):207-212

[10] Fowler CJ, Wiberg A, Oreland L, Marcusson J, Winblad B. (1980) The effect of age on the activity and molecular properties of human brain monoamine oxidase. J Neural Transm.;49:1-20 
[11] Hagymási K, Blázovics A, Lengyel G, Kocsis I, Fehér J (2001) Oxidative damage in alcoholic liver disease, Eur. J. Gastroenterol, Hepatol 13(1):49-53

[12] Heikkila RE, Cohen G (1972) Futher studies on generation of hydrogen peroxidase by 6-hydroxidopamine: potentiation by ascorbic acid. Mol Pharmacol: 241-248

[13] Horiuchi N, Nakagawa K, Sasaki Y Minato K, Fujiwara Y, Nezu K, Ohe Y, Saijo N (1988) In vitro antitumor activity of mitomicyn C derivative (RM-49) and a new anticancer antibiotic (FK 973) against lung cancer cell lines determined by tetrazolium dye (MTT) assay. Cancer Chemother Pharmacol 22(3):246-250

[14] Jorgensen M, Vendelbo B, Skakkebaek NE, Leffers H. (2000) Assaying estrogenicity by quantitating the expression levels of endogenous estrogen-regulated genes. Environ Health Perspect. 108:403-412.

[15] Knoll J, Ecseri Z, Kelemen K, Nievel J, Knoll B (1965)Phenylisopropylmethylpropinylamine (E-250), a new spectrum psychic energizer. Arch Int Pharmacodyn Ther 155(1):154-164

[16] Knoll J, Magyar K (1972) Some puzzling pharmacological effects of monoamine oxidase inhibitors. In: Costa E, Sandler M editors. Monoamine Oxidases - New Vistas. Adv. in Biochem. Psychopharmacol. Raven Press, New York 5:393-408

[17] Knowlden JM, Gee JM, Bryant S, McClelland RA, Manning DL, Mansel R, Ellis IO, Blamey RW, Robertson JF, Nicholson RI (1997) Use of reverse transcription-polymerase chain reaction methodology to detect estrogen-regulated gene expression in small breast cancer specimens. Clin Cancer Res, 3(11):21652172

[18] Kocsis Zs, Marcsek ZL, Jakab MG, Szende B, Tompa A (2005) Chemopreventive properties of transresveratrol against the cytotoxicity of chloroacetanilide herbicides in vitro. Int $\mathrm{J}$ Hyg Environ Health 208(3)211-218

[19] Liu M, Kelley MH, Herson PS, Hurn PD (2010) Neuroprotection of sex steroids. Minerva Endocrinol 35(2):127-143

[20] Magyar K, Pálfi M, Tábi T, Kalász H, Szende B, Szökő E (2004) Pharmacological Aspects of (-)-Deprenyl. Current Medical Chemistry 11(15):2017-2031

[21] Magyar K, Szende B, Lengyel J Tarczali J, Szatmáry I (1998) The neuroprotective and neuronal rescue effects of (-)-deprenyl. J. Neural Transm. 52:109-123

[22] Marcsek Z, Kocsis Zs, Jakab M, Szende B, Tompa A (2004) The efficacy of Tamoxifen in estrogen receptorpositive breast cancer cells is enhancement by a medical nutriment. Cancer Bioth and Rad 19(6):746-753

[23] Mosmann T (1983) Rapid colorimetric assay for cellular growth and survival: Application to proliferation and cytotoxicity assays. Journal of Immunological Methods 65(1-2):55-63

[24] Qin F, Shite J, Mao W, Chang-seng Liang (2003) Selegiline attenuates cardiac oxidative stress and apoptosis in heart failure: association with improvement of cardiac function. Eur. J. Pharmacol 461(2-3):149-158

[25] Saldanha CJ, Kelli A Duncan, Bradley J Walters (2009) Neuroprotective Actions of Brain Aromatase. Front Neuroendocrinol 30(2):106-118

[26] Salo PT, Tatton WG (1992) Deprenyl reduces the death of motoneurons caused by axotomy. J Neurosci Res 31(2):394-400

[27] Saura J, Richards JG, Mahy N (1994) Differential age-related changes of mao-a and mao-b in mouse brain and peripheral organs. Neurobiol Aging 15(4):399-408

[28] Schmittgen TD, Zakrajsek BA (2000) Effect of experimental treatment on housekeeping gene expression: validation by real-time quantitative RT-PCR. J Biochem Biophys Meth 46(1-2):69-81

[29] Simon L, Szilágyi G, Bori Z, Telek K, Magyar K, Nagy Z (2005) Low dose (-)deprenyl is cytoprotective: it maintains mitochondrial membrane potential and eliminates oxygen radicals. Life Sci 78(3):225-231

[30] Szende B, Bökényi Gy, Bocsi Gy, Kéri G, Timár F, Magyar K (2001) Anti-apoptotic and apoptotic action of (-)-deprenyl and its metabolites. J Neutral Transm 108(1):25-33

[31] Szende B, Magyar K, Szegedi Zs (2000) Apototic and antiapoptotic effect of (-)-deprenyl and (-)-desmethyldeprenyl on human cell lines. Neurobiology 8(3-4):249-255

[32] Tatton WG, Chalmers-Redman RM, Elstner M, Leesch W, Jagodzinski FB, Stupak DP, Sugrue MM, Tatton NA (2000) Glyceraldehyde-3-phosphate dehydrogenase in neurodegeneration and apoptosis signaling. J Neural Transm 60:77-100

[33] Tatton WG, Chalmers-Reddman RM, Ju WJ, Mammen M, Carlile GW, Pong AW, Tatton NA (2002) Propargylamines induce antiapoptotic new protein synthesis in serum- and nerve growth factor (NGF)withdrawn, NGF-differentiated PC-12 cells. J Pharmaciol Exp Ther 301(2):753-764

[34] Tatton WG, Ju WYL, Holland DP Tai C, Kwan M (1994) (-)-Deprenyl reduces PC12 cell apoptosis by inducing new protein synthesis. J. Neurochemistry 63(4):1572-1575 
[35] Toran-Allerand CD (2004) A Plethora of Estrogen Receptors in the Brain Where Will It End? Endocrinology 145(3):1069-1074

[36] Toronyi É, Hamar J, Magyar K, Szende B (2002) Antiapoptotic effect of (-)-deprenyl in rat kidney after ischemia-reperfusion Med. Sci. Monit 8(2):BR65-68

[37] van Erp PEJ, Brons PPT, Boezeman JBM, De Jongh GJ, Bauer FW (1988) A rapid-flow cytometric method for bivariate bromodeoxyuridine/DNA analysis using simultaneous proteolytic enzyme digestion and acid denaturation. Cytometry 9(6):627-630

[38] Wadia JS, Chalmers-Redman RME, Ju WJH. Carlile GW, Phillips JL, Fraser AD, Tatton WG (1998) Mitochondrial membrane potential and nuclear changes in apoptosis caused by serum and nerve growth factor withdrawal: time course and modification by (-)-deprenyl. J. Neurosci 18(3):932-947

[39] Wong WK, Ou X-M, Chen K,. Shih JC. (2002) Activation of Human Monoamine Oxidase B Gene Expression by a Protein Kinase C MAPK Signal Transduction Pathway Involves c-Jun and Egr-1. J Biol Chem 277:22222-22230

Citation: Zoltán Marcsek, et.al., (2019). Cytoprotective Effects of (-)-Deprenyl Might be Due to its Estrogen Receptor Stimulatory Activity in Vitro. ARC Journal of Pharmaceutical Sciences (AJPS), 5(3), pp.17-26. DOI: http://dx.doi.org/10.20431/2455-1538.0503004

Copyright: () 2019 Authors. This is an open-access article distributed under the terms of the Creative Commons Attribution License, which permits unrestricted use, distribution, and reproduction in any medium, provided the original author and source are credited. 